\title{
Higher Education Policies in Central and Eastern Europe: Convergence toward a Common Model?
}

\author{
MICHAEL DOBBINS* and CHRISTOPH KNILL*
}

Contrary to many other areas, international and, in particular, European influences on national policymaking in higher education (HE) have remained limited. This picture, however, changed fundamentally from the late 1990s onward. In 1999, 29 countries signed the Bologna Declaration, denoting the start of the so-called Bologna Process. Thus, a collective supranational platform was developed to confront problem pressure, which has in turn fostered considerable domestic reforms. However, we still have limited knowledge on whether the Bologna Process has actually led to the convergence of national HE policies toward a common model. This article analyzes these questions by focusing on Central and Eastern European (CEE) countries. Because of its tumultuous and inconsistent path of development and the sheer magnitude of the current reform processes, CEE HE stands out as a particularly worthwhile object of analysis for scholars interested in policy convergence as well as policy legacies and path dependencies.

\section{Introduction}

Contrary to many other areas, international and, in particular, European influences on national policymaking in higher education (HE) have remained limited. For a long time, deeper integration and cooperation in HE policy or even the establishment of a common European Higher Education Area (EHEA) seemed unthinkable, with European-wide cooperation being restricted to EU-mobility programs. This picture, however, changed fundamentally from the late 1990s onward. In 1999, 29 countries signed the Bologna Declaration, denoting the start of the so-called Bologna Process. With this document the signatory countries agreed on establishing an EHEA by 2010. Thus a collective supranational platform was developed to confront problem pressure, which has in turn fostered considerable domestic reforms. Although the degree and speed of change vary considerably across countries, the signatory countries have started to develop policies "that fit the European agenda towards converging systems of higher education" (Huisman and Van der Wende 2004, 355).

Essentially, the Bologna Process is the culmination of and European answer to other protruding external factors such as the knowledge society *University of Konstanz 
(Corbett 2005), demographic changes, and the impact of globalization. Unlike other Europeanized policy areas though, the Bologna Process exclusively rests on voluntary agreements on, for example, harmonizing study structures (Bologna Declaration 1999), enhancing academic mobility and increasing university autonomy and administrative capacity (Bologna Declaration 1999; Prague Communiqué 2001), the incorporation of students as equal partners (Berlin Communiqué 2003), and quality assurance (Bologna Declaration 1999; Prague Communiqué 2001). These jointly agreed objectives are monitored and promoted by means of institutionalized communication, benchmarking measures, and information exchange in transnational policy networks. These networks materialize through biannual ministerial meetings, at which the implementation of joint objectives is addressed, but above all through the so-called follow-up groups, national committees, and national Bologna groups supporting the responsible ministries. They consist of representatives of the various Bologna countries and the EU, who jointly draw up concrete plans for the realization of the Bologna objectives. The follow-up groups are in turn advised by Europe-wide university associations (e.g., the European University Association, the European Association of Higher Education Institutions, and Education International), students' associations (ESIB), Business Europe, and the Council of Europe. However, contrary to other EU policy areas, there are no legally binding requirements that oblige the signatory states to implement reforms and there is no central steering authority.

Nevertheless, as a result of this European framework, a massive expansion of transnational communication and interlinkages has occurred, which provides a potential platform for policy exchange, inspiration, and borrowing (Phillips 2005). However, we still have limited knowledge on whether the Bologna Process has actually led to the convergence of national HE policies toward a common model. After all, other preexisting factors and arrangements are also likely to have had a transforming impact on European education systems. These include, to mention a few, cooperation with the Organisation of Economic Co-operation and Development (OECD) and World Bank, the spread of New Public Management to broad segments of society, and also the engagement of the EU in education even before the onset of the Bologna Process (Maassen and Olsen 2007).

As it is often difficult to disentangle Bologna from these related convergence-promoting factors, we will examine the effects of transnational communication during two time periods, the pre-Bologna phase and the Bologna phase. Have domestic HE policies converged toward a common model already before or only during the Bologna Process? Or are reforms shaped by domestic paths and legacies, without any movement towards a dominant HE approach?

This article analyzes these questions by focusing on Central and Eastern European (CEE) countries. As a result of its tumultuous and inconsistent path of development and the sheer magnitude of the current reform 
processes, CEE HE stands out as a particularly worthwhile object of analysis for scholars interested in policy convergence as well as in policy legacies and path dependencies. The peculiarity of CEE universities is their dichotomy between institutional endurance and repeated institutional makeovers. The circumstances of the transformation and transnationalization process (Martens, Rusconi, and Leuze 2007) provided the impetus not only for the renaissance of past models and unique domestic strategies but also for the spread of policy models conveyed through transnational processes of communication and information exchange, in particular the Bologna Process.

To assess the degree of policy convergence, we focus on patterns of HE governance. Although the Bologna Process does not prescribe a particular model of governance, market-oriented solutions have predominated discourse and are actively promoted by the EU Commission, which has become increasingly engaged in the process (European Commission 2003). To get an encompassing picture of policy developments over time, we deliberately lay down a broad and multifaceted definition of HE governance, which comprises patterns of control, coordination, and the allocation of autonomy among three levels-the state, professoriate, and university management. Our understanding of governance hence includes what we regard as the three crucial levels of HE governance, which are currently subject to pressures for change: (1) the organizational structure of universities including personnel and funding issues, (2) the state's regulatory approach, and (3) the relations among universities, external stakeholders, and society (McDaniel 1996). As a conceptual framework for addressing the direction of policy change, we draw on three historically anchored models of HE governance, the "Humboldt" model of academic self-rule, the market-oriented model, and the state-control model. We analyze convergence and change of HE governance for four CEE countries that differ in their precommunist and communist legacies with regard to these historical models (Bulgaria, Czech Republic, Poland, and Romania).

\section{Theories and Hypotheses}

Our central objective is to analyze the extent to which the HE policies of the four countries under study have converged on a common model of HE governance over time. Policy convergence has emerged as a broadly studied phenomenon in the social sciences (Bennett 1991; Dolowitz and Marsh 2000; Drezner 2001; Knill 2005), including also studies examining convergence in HE degree structures (Bleiklie 2001; Rakic 2001; Witte 2006). While all three studies introduce a political science perspective, the first two, in particular, remain at a rather descriptive level rather than trying to systematically explain domestic policy changes from a comparative perspective. This study seeks to reduce this research gap by benefiting from approaches undertaken for other policy areas. Recent studies have conducted more systematic, theory-driven testing to determine whether 
domestic and transnational factors account for increasing policy similarity, while placing greater focus on the impact of transnational communication (e.g., Holzinger, Knill, and Sommerer Forthcoming).

We measure convergence in HE in CEE countries by looking at their distance to a certain policy model (i.e., delta convergence; Heichel, Pape, and Sommerer 2005). We distinguish among four time frames: the precommunist phase ( $\mathrm{t} 1)$, the communist phase ( $\mathrm{t} 2)$, the pre-Bologna phase up to 1999 (t3), and the Bologna phase from 1999 to the present (t4). Our independent variables are conceived as driving forces behind policy change and inertia, and consist of exogenous and endogenous factors that potentially "push" or "pull" HE systems toward a certain policy model. In this regard we focus, in particular, on the effects of institutional legacies and institutional isomorphism.

Although we by no means repudiate the assumption that policy change is driven by actors and their rationales, we are primarily interested in the analysis of the general institutional structures in which actors operate and thus impact their strategic interactions. Moreover, we do not neglect the explanatory potential of other-especially socioeconomic-factors, like massification, increasing student numbers, or public debt. However, these factors not only reveal a rather similar constellation across the countries under investigation, but also have undergone massive increases before the onset of the Bologna Process. As a consequence, no systematic focus is placed on these aspects for the purpose of the following analysis.

\section{Exogenous Factors: Normative and Mimetic Isomorphism}

According to DiMaggio and Powell (1991), institutional isomorphism may constitute an important source of policy convergence. It places particular emphasis on the explanation of domestic changes by developments in the organizational environment and has been applied to explain the international spread and diffusion of policy innovations and reform concepts (DiMaggio and Powell 1991). The central argument is that legitimacy rather than functional efficiency is the major driving force of organizational change. To increase their legitimacy and ensure their persistence, organizations embrace rules, norms, and routines that are widely valued in their organizational environment.

An important driving force of isomorphic organizational change emerges from coercion. Organizations adjust their structures and procedures to organizations on which they are financially or legally dependent (DiMaggio and Powell 1991, 74). However, organizational adjustment to the environment may also occur in constellations of high uncertainty, for example, ambiguous goals, uncertain means-end relations, or confrontation with new problems. In such constellations it is argued that organizations imitate the structures of other organizations, which they perceive as particularly successful. Instead of a long-winded search for own solutions to problems, organizations strive to ensure their legitimacy by emulation. 
Another mechanism driving isomorphic change is based on similar dominant normative orientations and beliefs. In this context, the impact of similar professional backgrounds and the role of professional organizations and epistemic communities in spreading common understandings and perceptions of policy problems and solutions are emphasized in the literature.

Given the voluntary and hence noncoercive nature of the Bologna Process, HE convergence may primarily result from mimetic and normative isomorphism, which-as argued earlier-place particular emphasis on institutionalized channels of transnational communication and information exchange. Looking at the nature and depth of HE networks existing in the pre-Bologna and Bologna phase, we arrive at different expectations for HE policy convergence.

For the pre-Bologna phase, we expect significant diversity in terms of the scope and nature of policy networks. This is substantiated by the loosely coupled highly fragmented nature of HE networks spanning from asymmetric networks between individual academics and HE providers to promoters of "forward thinking" such as the OECD and World Bank (Stone 2004, 553). However, despite being transnational agents of policy diffusion (Martens, Rusconi, and Leuze 2007), such organizations essentially have cooperated bilaterally with individual countries while only making unbinding policy recommendations for HE every few years. Hence, in the aftermath of communism, a more uniform European system of accountability, guidance, and benchmarking was lacking. Consequently, interlinkages between CEE university management, academics, HE policymakers starkly differed with regard to depth, nature, and orientation. Based on these considerations, we hypothesize:

H1: HE policies in CEE countries will develop toward different models of governance in the pre-Bologna phase ( $t 3)$ because of the different degree and nature of their transnational interlinkages.

The nature of the Bologna Process gives us reason to believe that transnational and communication may generate the opposite effect in $t 4$, that is, policy convergence. First, the Bologna Process creates a tightly knit transnational HE regime that facilitates communication and the elaboration of norms and common solutions. It provides a structured platform driven by norm- and rule-oriented problem-specific coordination. Second, the Bologna platform has become a bourse of interests and ideas (Vaira 2004), now incorporating the interests of national governments, students, university managers, and European institutions (see Walter 2006). Hence, the process is likely to facilitate the elaboration of innovative policy models and emulation of approaches perceived as successful. Third, Bologna radiates pressure for national systems to assert their legitimacy in a competitive European environment and under "international scrutiny" (Knill 2005). Finally, the European Commission has been increasingly incorporated into the process and put forward a clear vision for 
European universities. This includes funding diversity, universityindustry cooperation, policies that "maximize the social return of the investment" into HE (European Commission 2003, 14) and hence an articulated preference for market-based instruments. Amid uncertainty over future developments (DiMaggio and Powell 1991, 70), drawing on such externally promoted policy models and best practice is a common strategy for perceived laggards, for example, new EU countries, to "catch up" during the integration process.

H2: HE policies in the CEE countries will converge toward a common model of governance during the Bologna phase (t4) because of the increasing homogeneity and institutionalization of transnational interlinkages.

\section{Endogenous Factors: Policy Legacies}

Convergence of HE governance is also influenced by endogenous factors and is by no means an automatic reaction to transnational pressures (Neave 2003). With regard to CEE transformation countries, emphasis has been placed on the relevance of precommunist and communist legacies. Such legacies may be exceptionally important because the university stands out as a historical institution par excellence, marked by relative continuity. This institutional memory may form the basis for patterns of governance and autonomy (Neave and van Vught 1991, x), in which vested interests and their underlying normative orientations may reduce the room for change. Thus, even external models viewed as successful might face resistance and inertia if they challenge dominant beliefs and institutional identities.

Precommunist legacies refer to the different types of HE coordination arrangements that existed before the communist regime (t1) (Sadlak 1995, 46). As argued by Offe $(1993,17)$, the design of new institutions may occur through the replication of old or spatially distant ones. Thus, policymakers may draw inspiration and legitimacy from models from the past of their own society. The precommunist context may serve as a referential system to cling onto, and a very typical attitude of CEE policymakers is the return to the "continuity of history" disrupted by the imposition of communist rule (Radó 2001, 14). Sadlak $(1995,46)$ distinguishes between countries that followed the Humboldtian ideal of freedom of the search of knowledge through teaching and research (e.g., Poland, Czech Republic) and those that leaned toward the French or Napoleonic concept of state coordination (e.g., Romania, Russia). Bulgaria was a historically volatile mixed type, with a slightly stronger Anglo-Saxon orientation in the early twentieth century. Thus, governance patterns from the precommunist past may provide a legitimate point of reference for HE reform:

H3: The more similar the HE policies of CEE countries were during the precommunist phase (t1), the more their HE policies will develop toward a similar model during the postcommunist phases $(t 3, t 4)$. 
Emphasizing the significance of precommunist legacies does not imply that the impact of the communist system can be neglected. The detachment from centralized control after 1989 does not necessarily entail the complete emancipation of universities from the vertical coordination structures of the communist regime (Tucker 2000). Historically entrenched patterns of action cannot be uprooted overnight. As decision makers tend to cling to existing institutions, communist path dependencies cannot be ruled out, regardless of the strength of ongoing isomorphic processes. The institutional fabric established over the communist phase, that is, state intervention, egalitarian values, may continue to have a massive impact on the steering and structuring of HE systems in the postcommunist phase (Radó 2001, 15). While in some countries all traces of academic self-management were eradicated (e.g., Romania, Bulgaria), other countries sustained limited autonomy over the design and orientation of academic programs (e.g., Poland, Czech Republic).

H4: The more similar the HE policies of CEE countries were during the communist phase (t2), the more their HE policies will develop towards a similar model during the postcommunist phases $(t 3, t 4)$.

\section{Indicators of Policy Convergence}

To measure the degree of change and convergence in HE policies, we rely on an ideal-typical distinction of three governance models (Clark 1983; Olsen 2007). In the state-authority model, universities are state-operated institutions marked by strong process control and limited autonomy. The state coordinates many aspects including admissions, curricula, and appointment of personnel, and actively influences quality assurance and university-business relations (Neave and van Vught 1991, xi-xxii). This explains the close oversight by government and a high degree of hierarchy. Historically, HE serves the formation of national culture and consensus and can promote socioeconomic transition and nation (re)building.

Founded upon Humboldt's principles, the model of self-governing communities of scholars (Scott 2002, 140-141) implies weak university management and strong professorial dominance and collegial control (de Boer and Goedegebuure 2003, 215). The model ideally is based on a stateuniversity partnership, governed by principles of corporatism and collective agreement. The state remains a potent actor thanks to diverse planning and financial laws. This limits self-governance but enables universities to establish normative principles of their own (Olsen 2007, 29). Socioeconomic needs are not streamlined into academic activities and student placement, while the university is committed to the search for truth through intellectual freedom-regardless of its immediate utility or political convenience. Paramount to this model is "collegial" governance through the professorial chair system, in which each chair constitutes a core organizational unit (Schimank 2002, 8) and thus "small monopolies in 
thousand parts" (Clark 1983, 140). Acting as "federations" of chairs, they can block initiatives of the government or university management.

Market-oriented models contend that universities function most effectively when operating as business-like enterprises (Dill 1997). Entrepreneurial management methods are regarded as legitimate organizational principles. The main thrust of power lies not with the professoriate but rather with university management, which strategically steers and positions the institution. Management sees itself as an entrepreneur offering academic services to students and external stakeholders who assume the role of quasiconsumers. Government involvement entails incentives and quality or product control rather than directives or manpower planning (Olsen 2007, 33), while institutions remain financially dependent on private donors and tuition. Subsequently, the "entrepreneurial" university and New Public Management approaches have come to dominate current discourse (Clark 1998), as they purportedly facilitate adaptation and innovation.

To empirically distinguish these three ideal types and systematically measure changes in governance, we compiled a schematic breakdown of indicators. In so doing, we deliberately opted for an analytical scheme that is transposable to other countries, hence providing a basis for generally comparing domestic policy change and policy convergence in the field of HE. Our categorization aims to provide a broad picture of contemporary university governance, which reflects the "tug-of-war" between the state, academia, and university management with regard to issues of autonomy over procedures. It also includes the changing relationship between universities and external stakeholders.

\section{Empirical Findings}

In the following, we present empirical evidence on the degree of and reasons for domestic changes in HE governance in the four studied countries. In doing so, we limit ourselves to public HE institutions, as they are historically institutionalized and the primary target of the state's HE policy with a much larger operational apparatus. In addition to the comparative analysis of legislative and policy documents, newspapers, and secondary literature, we conducted semistructured interviews with HE policymakers from each country. They included current and former members of government or responsible ministries, university staff, and management involved in policy reforms (rectors, vice-rectors), and intermediate level representatives. A list of interview partners is provided in the Appendix.

\section{The Czech Republic: The Long Shadow of Humboldt}

Of the four examined countries, Czech HE has the longest history, dating back to the establishment of Charles University in 1348. The prewar Czech 
system ( $\mathrm{t} 1$ ) was firmly rooted in the Humboldtian tradition of academic self-rule (Kotásek 1996, 44; Scott 2002, 340), while the phase after the communist takeover (t2) was synonymous with the "deHumboldtization" of Czech(-oslovak) universities. This entailed the complete abolition of university autonomy, a rapid shift toward the state control model, and rigid ideology-based policy (Hendrichová and Šebková 1995, 105). The post-1989 course of events was equally swift and dramatic, as "academic self-governance" was immediately reintroduced and the academic community mobilized and consolidated to distance itself from the state. Policymakers sought to reinstate the idea of the Humboldtian university, bolstered by internal democratic structures and external buffer organizations. The reestablishment of "free" universities, like free parliaments (Scott 1993, 431), also allowed for the broad participation of students in representative bodies. The restoration of the chairbased system (Interview CZ-1; see the Appendix) quickly transformed the once hierarchical system into a highly fragmented one, in which autonomy over substantive and procedural affairs was fragmented down to the chair level. The Higher Education Act of 1990 granted universities control over all aspects of substantive autonomy, including admission criteria, teaching, and research programs (Interviews CZ-4, CZ-2). With regard to personnel autonomy, the newly established system represented an extreme form of academic self-governance. High- and low-level academic staff were elected solely by other high-ranking faculty staff, without state review. This equally pertains to rectors, who were chosen by fellow academics and shared collegial governance powers with them.

The Higher Education Act contained several additional features significant for understanding the governance system. Essentially, anything indicative of central control was banished (Cerych 2002). de Boer and Goedegebuure $(2003,219)$ even speak of the "abolition of government." For policy change, the ministry also required the consensus of the Czech Rectors' Conference and Council of HE Institutions, which only included academics, thus no external stakeholders. Using the terminology of Neave and van Vught (1991, 251-252), the state relinquished both product and process control in Czech HE. In fact, the only means for the state to shape the regulatory framework was through funding instruments. The Czech system remained heavily subsidized by the state, which in turn allocated earmarked funds to institutions. Instead of opting for a market-oriented solution with, for example, tuition and contract-based universitybusiness cooperation, the ministry continued to entirely fund HE. Initially, the level of funding remained incremental to the previous year's funding and negotiation based (Interview CZ-1). Despite the switch to lump-sum funding in 1992 (Jongbloed 2003, 128), performance-based criteria were not yet considered.

The transnational dimension also profoundly affected Czech HE. However, these effects were primarily restricted to quantitative-structural aspects (student numbers, the establishment of polytechnics). In other 
words, governance was only slightly affected by the policy models conveyed through transnational networks in t3. Instead, the Humboldtoriented path after 1989 was reinforced by three primary motivations: the drive for democracy, precommunist traditions, and linkages with Western countries, Germany and Austria in particular. Although they did not provide a blueprint for reform, references to German and Austrian legislation added substantiation to the Czech model of self-governance (Interview CZ-3). Instead of aligning themselves with "entrepreneurial universities" (Clark 1998; Sporn 2006), policymakers concocted a novel system of quasiparliamentary governance and checks and balances, clearly motivated by the oversensitivity to external intervention (Interview CZ-5).

Highly instructive for understanding the dynamics of Czech HE is its cooperation with the OECD, which drew up recommendations concerning problematic aspects of the post-1989 system (OECD 1992, 139; Stastna 2001, 478). Besides the expansion and modernization of HE, the OECD proposed the establishment of an independent advisory think tank to address competitiveness and technological progress (Cerych 2002, 117; OECD 1992). Moreover, the OECD called for more efficient managementbased internal HE structures and diversified funding, as well as for the expansion of polytechnic-like institutions.

The ensuing expansion of Czech HE was indeed based on the emulation of foreign models. Following the OECD recommendation, a Dutch university association (HBO-Raad) allocated funding for the creation of nonuniversity professional institutions. However, the OECD's appeal for increased strategic management was shrugged off by the academic lobby, fearing the imposition of a master plan by the state. A similar scenario applies to the recommendation for more efficient internal structures, greater management accountability and nonstate funding. Instead of devolving greater power to university management, Czech academics came to master the "art of freedom" and use autonomy to block reforms (Mateju 2004). In fact, changes were only implemented in those areas that did not alter the governance structures established post-1989. Hence, the impact of transnational interlinkages remained restricted to system expansion and "capacity building," that is, new international relations departments and continuing education centers (Stastna 2001, 476).

Is the Czech system of governance marked by the same degree of inertia in the Bologna phase? First, the modified Higher Education Act of 1998 gave the state more leverage over product control. This entailed the establishment of a state accreditation body, which consists exclusively of academics and thus excludes economic stakeholders. Contrary to the previous practice of peer review, the accreditation body now evaluated ex post performance (Interview CZ-5). More significant, however, is the array of aspects unchanged post-1999-despite the more integrative and homogenous transnational framework. These include the power of the 
professoriate, strong collegial control, the dominance of academia in governing bodies, and lacking entrepreneurialism in management.

Nevertheless, the Bologna platform has prompted Czech policymakers to introduce a series of novelties, which arguably are paving a rather rocky path towards the "semimarketization" of Czech HE. For example, amendments to the Higher Education Act triggered by right-wing parliamentarians alluding to the Bologna Process led to the implementation of the two-tier degree structure, but also stronger ties to knowledge-related enterprises, free and fee-based funding and greater transparency in admissions (Matěju and Simonová 2003). A stronger market orientation is evident with regard to the diversification of funding through strategic investments and private contracts. At the same time, the country is moving from input to output-based funding, inspired - to a large extent-by the British model (Interview CZ-5).

Altogether, though, the fragmented and relatively isolated system of governance that emerged post-1989 demonstrates a lack of executive leadership and transfaculty coordination and is hence best described as a collegially governed "federation of chairs." This can be explained by the relatively inward-looking nature of the academic community (Interview CZ-2). The Bologna platform has provoked academic policymakers to partake in "unconscious inspiration" by foreign trends (Interview CZ-6), leading to greater problem pressure and the sluggish introduction of market-oriented and managerial instruments. However, in the Czech context it is not a matter of legitimacy amid competition, rather selecting and borrowing best practice that is compatible with the historically rooted sensitivities of the academic community. These sensitivities, combined with the many veto points and lack of executive steering, have clearly served to uphold the Humboldt-oriented chair system.

Referring back to the indicators drawn up in Table $1, H$ symbolizes the ideal type of academic self-governance (Humboldt model), $M$ represents the feature typical of market-oriented systems, while $S$ is indicative of state-centered governance. A " $\rightarrow$ " represents a move in the given direction during the respective timeframe (Table 2).

\section{Bulgaria: The Rocky Path toward Marketization}

In $\mathrm{t} 1$, Bulgarian academic policymakers put in practice trends from all three historical models of coordination. Initially the state drew on the French tradition of education as a vehicle for national cohesion and identity (Georgieva 2002, 15). Faced with overly zealous state control, academics increasingly tapped into German influences, which resulted in the incorporation of free scholarly inquiry into the university (Boiadjieva 2005) and somewhat later Anglo-Saxon notions of centralized selfmanagement in order to create a buffer against state intrusions and manage externally funds (Gocheva 2002, 7). In t2 the Bulgarian HE system constituted a hybrid of Stalinist and Napoleonic features with extreme 


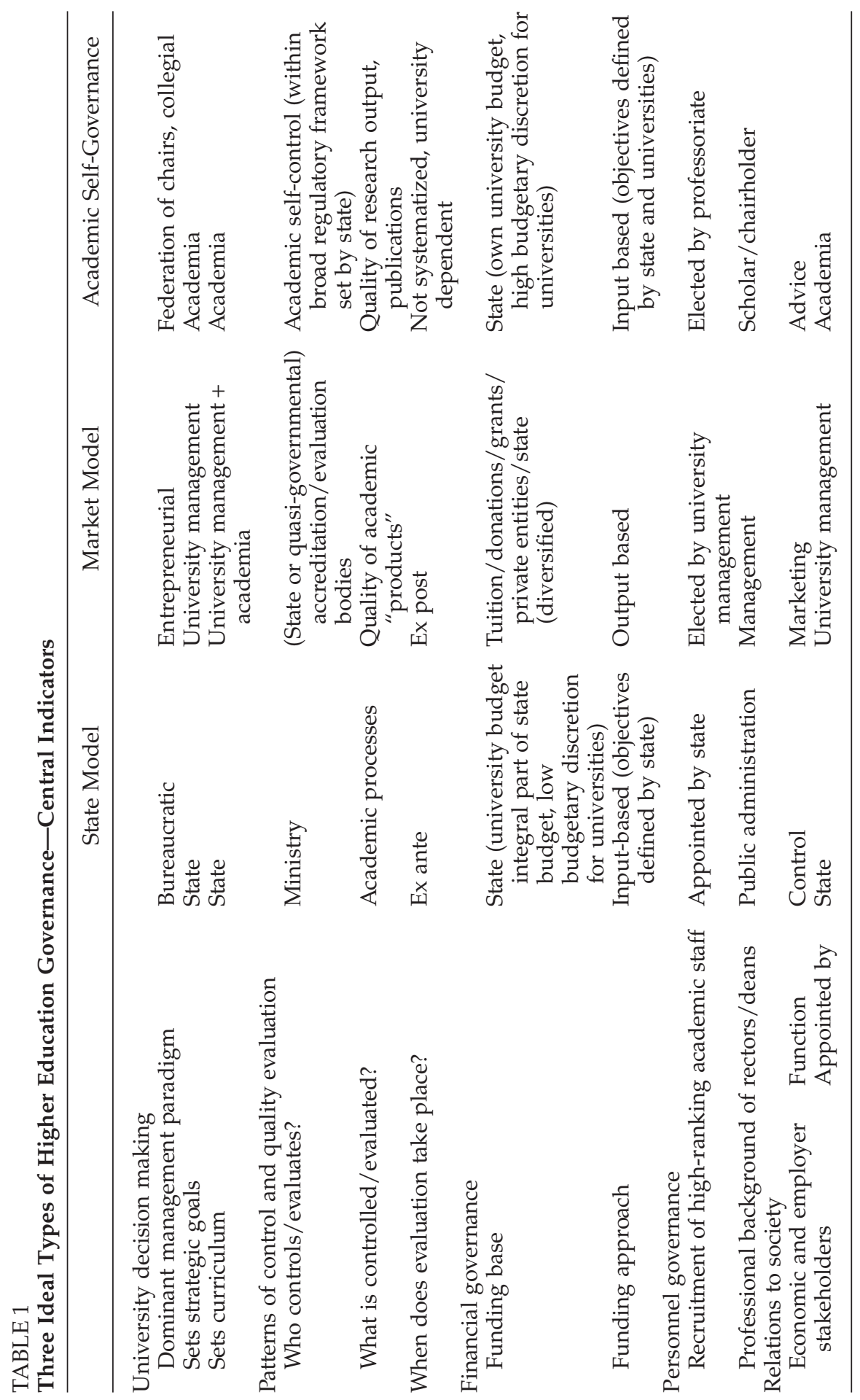




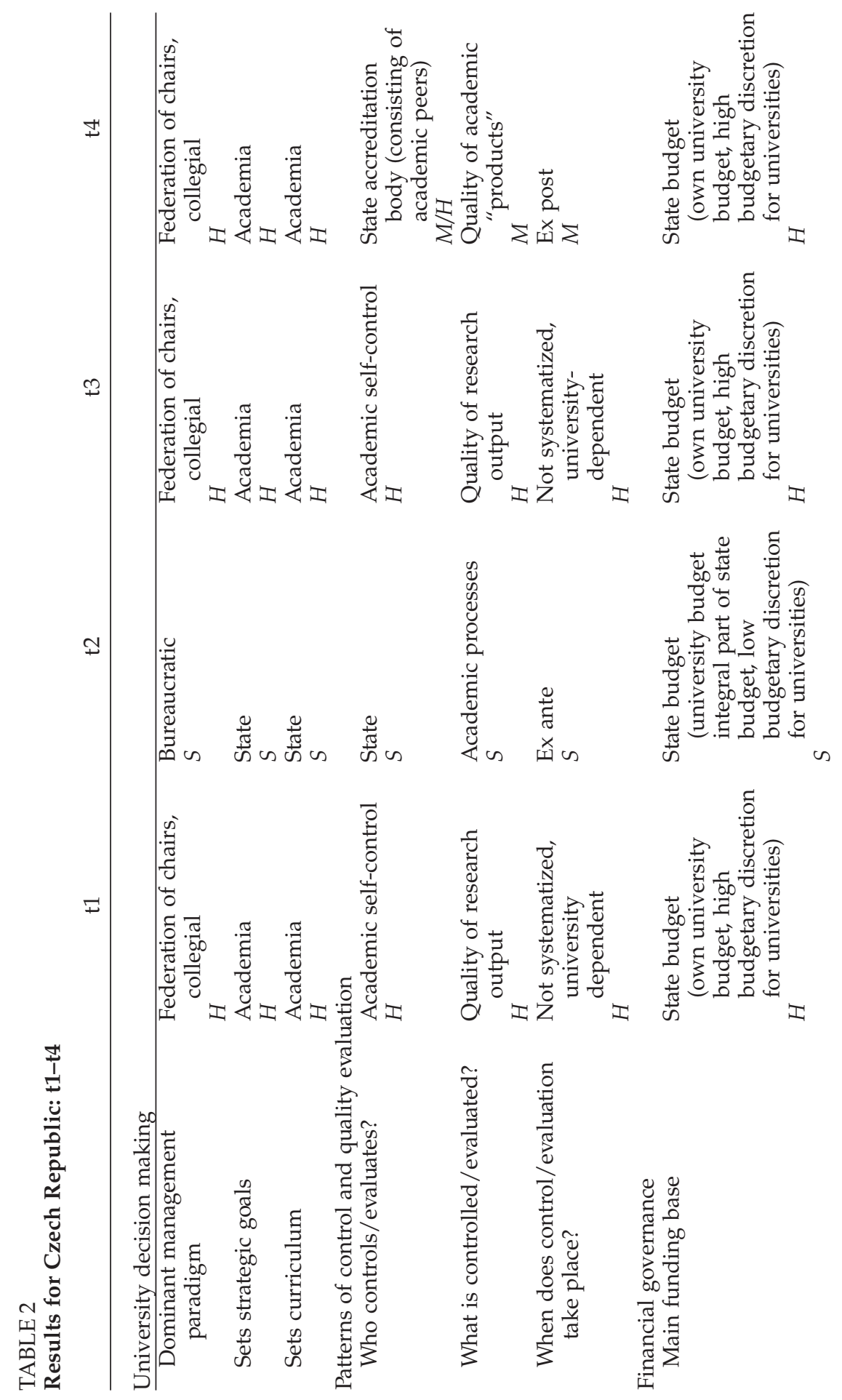




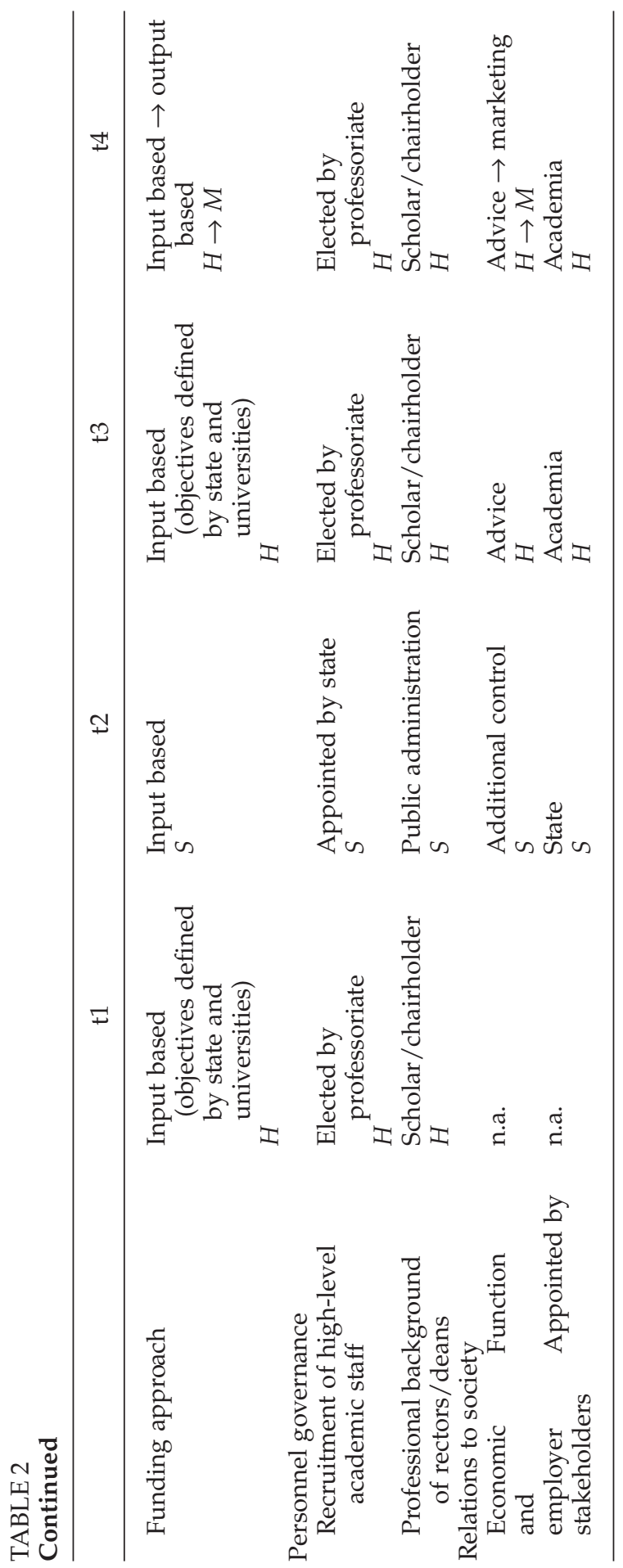


centralization and ideological predetermination of all activities. In the postcommunist phase Bulgaria initially followed the same storyline as the Czech Republic with a swift move toward "academic oligarchy" (Interview BG-1). However, no HE act was issued in the initial phase. Instead, policymakers only legally codified academic autonomy, without a legal framework for system governance. Hence, instead of clear principles and legislation regulating the relationship between the state and HE providers, academics conceived the reintroduction of autonomy as a political action to accelerate the erosion of totalitarianism. Study content was determined at faculty level and via academic senates, without government influence. Personnel autonomy was also vested at faculty level. The managerial powers of rectors remained watered down compared to more marketoriented systems.

This led to a situation of unfettered autonomy in which academics pursued a course of fragmented expansion. Individual faculties sought to achieve the status of HE institutions, enabling them to collect tuition fees. Not only did the number of universities increase from 5 to 40, but student numbers also increased uncontrollably, despite the lack of adequate facilities and staff (Interview BG-1). Instead of establishing effective university management systems, academics utilized the liberal regulations to shield themselves from external control, often demonstrating rent-seeking behavior in the procurement and management of tuition funds (Interview BG-2).

With regard to transnational isomorphism, interlinkages with Western Europe initially were weak, as academic policymakers remained rather "introverted" (Interview BG-2). However, this changed incrementally as a consequence of the recentralization of Bulgarian HE in the mid-1990s. Unlike their Czech counterparts, Bulgarian academics did not sufficiently insulate themselves from the state or effectively manage their autonomy. With the Higher Education Law of 1995, the pendulum shifted back to state control. This was manifested by Uniform State Requirements, a registry of state-authorized programs on the basis of which the state regulated accession conditions and funding. Suddenly, the state had created a control cycle, in which funds were determined by student numbers, and student numbers were determined by the state.

While recentralization initially was aimed at preventing the system from sliding into disarray, the Ministry increasingly strived to draw up a reform package to bring the system in line with European standards (Georgieva 2002). Recentralization enabled the Ministry to tighten links to the international level to accompany a more coherent reform strategy. This was exemplified by the World Bank's involvement in Bulgarian education and the Ministry's efforts to emulate the British accreditation model (Interview BG-3). However, the ideational inspiration via transnational platforms did not translate into effectively functioning institutions. ${ }^{1}$ This was further complicated by frequently shifting governmental coalitions, competing ministerial objectives, and politics of stop-and-go. Moreover, academics, 
who widely perceived the state as intervening where it should not, for example, student numbers, structural issues, remained unreceptive to the state-managed strategies for adopting HE to contemporary demands.

Before Bologna, Bulgaria found itself lodged between state control and fragmented academic interests but also increasingly imbedded in a web of transnational networks. The evidence demonstrates that Bologna has not radically transformed Bulgarian HE. However, by introducing an overarching inspirational platform, it has added coherence and direction to previously initiated policies, which were often interrupted and stalled by coalition breakdowns and weak administrative capacity (Slantcheva 2004, 258). The current status quo is hence best described as a mixed model of state authority and academic oligarchy, with market-based governance as the clear trend. There are indications of this shift at the state and university levels. The Accreditation Agency, the main vehicle of EU networking, has moved away from a state-serving to output-oriented, ex post approach. Previously, focus was placed on the proper implementation of legal regulations, whereas accreditation now aims to stimulate universities to establish their own output-oriented accreditation systems to be evaluated by the agency (Interviews BG-2, BG-3, BG-4). According to the interviewees, Bologna-based networking with Great Britain in particular has also flanked reforms in the funding system. This includes the diversification of funding sources and the fact that, since 2001-2002, universities receive money per student, no longer per professor. However, funding is still subject to a parliamentary decision, then itemized and controlled by the Ministry, which now partially pegs allocation to accreditation outcomes (Interviews BG-3, BG-5).

Drawing on the English system, the state has also presented a nonbinding blueprint for effective university management and employer relations. As a likely side effect of Bologna, there is a marked trend toward more managerialism, not least with regard to internal allocation of funding. And resulting from the imitation of market-oriented models, the Accreditation Agency and Rectors' Conference have also-with increasing success-organized meetings with business representatives to stimulate synergies between market and academic demands (Interviews BG-3, BG-4). Obstacles to a more entrepreneurial approach are, however, the multitude of state regulations and the limited four-year term of rectors, who have little incentive to perform well.

Altogether, though, the broader trend toward marketization can be regarded as a spin-off of the Bologna Process and the swift development of the market itself. Although Bologna has not triggered profound reform at system's core, the web of networks has enabled policymakers to more clearly define their aims and expectations in line with readily available examples of best practice (Interviews BG-4, BG-5). However, Bulgaria is still marked by its rather underdeveloped and unsystematic policy process, which has lacked critical elements for a successful reform course, for example, systematic assessment of potentials and constraints, broad 
coalition building and the synergetic leadership of policy entrepreneurs. The result has been a patchwork of occasional legislative changes, which despite all incoherencies exhibit a gradual shift toward the market paradigm (Table 3).

\section{Romania: A Text-Book Case of Isomorphism}

The Romanian case demonstrates how learning and emulation inspired by transnational networking can provide an impetus for paradigmatic change and a successful reform course. In the precommunist phase, Romanian HE was marked by the disproportionate role of the state (Scott 2002, 140-141), although the Humboldt model became more predominant between 1920 and 1950 (Interview RO-2). During the communist phase, remaining traces of academic autonomy were abolished, while universities were transformed into labor-force breeding units in line with ideological norms (Mihailescu and Vlasceanu 1994, 76). However, as a consequence of Ceaussescu's "divorce" from Moscow, a slight liberalization of the academic sphere took place and academic cooperation with the West developed rapidly, enabling academics to participate in technology transfer (Sadlak 1995).

Unlike the previous cases, no extensive reforms to uproot the logic of the system were pursued immediately after 1989 (Nicolescu 2002, 92-93). Universities were granted de facto autonomy, yet only in a limited and inconsistent manner. The ministry continued to establish goals, strategies, and an overarching framework for universities (Interviews RO-1, RO-2). In view of weak self-management traditions in Romania, the state demonstrated great reluctance in granting universities greater procedural and substantive autonomy. Accustomed to acting with restraint vis-à-vis an omnipotent state, academia also was unable to mobilize for more selfmanagement powers.

By the mid-1990s, HE was still state controlled and funded, while individual institutions functioned under the pressure of corruption, instead of accountability, competition, and transparency (Marga 1998). At this point, drastic changes were triggered as a result of domestic problem pressure, lesson drawing, and ministerial activism. Subsequent to reforms initiated by Education Minister Andrei Marga, the state relinquished its role as a system designer and sought inspiration from market-based systems to impose more competitiveness and entrepreneurialism. The ministry was restructured according to management methods, and reforms were introduced to promote new teaching methods and performance-based criteria (Marga 2002, 130). Moreover, the reform package entailed a switch away from formula funding to lump-sum funding. The ministry granted HE institutions financial incentives for attracting additional nonstate funds and introducing tuition (Interview RO-3). The evidence suggests that isomorphic effects already came to bear before Bologna, as international trends were continually referred to during reform negotiations and 


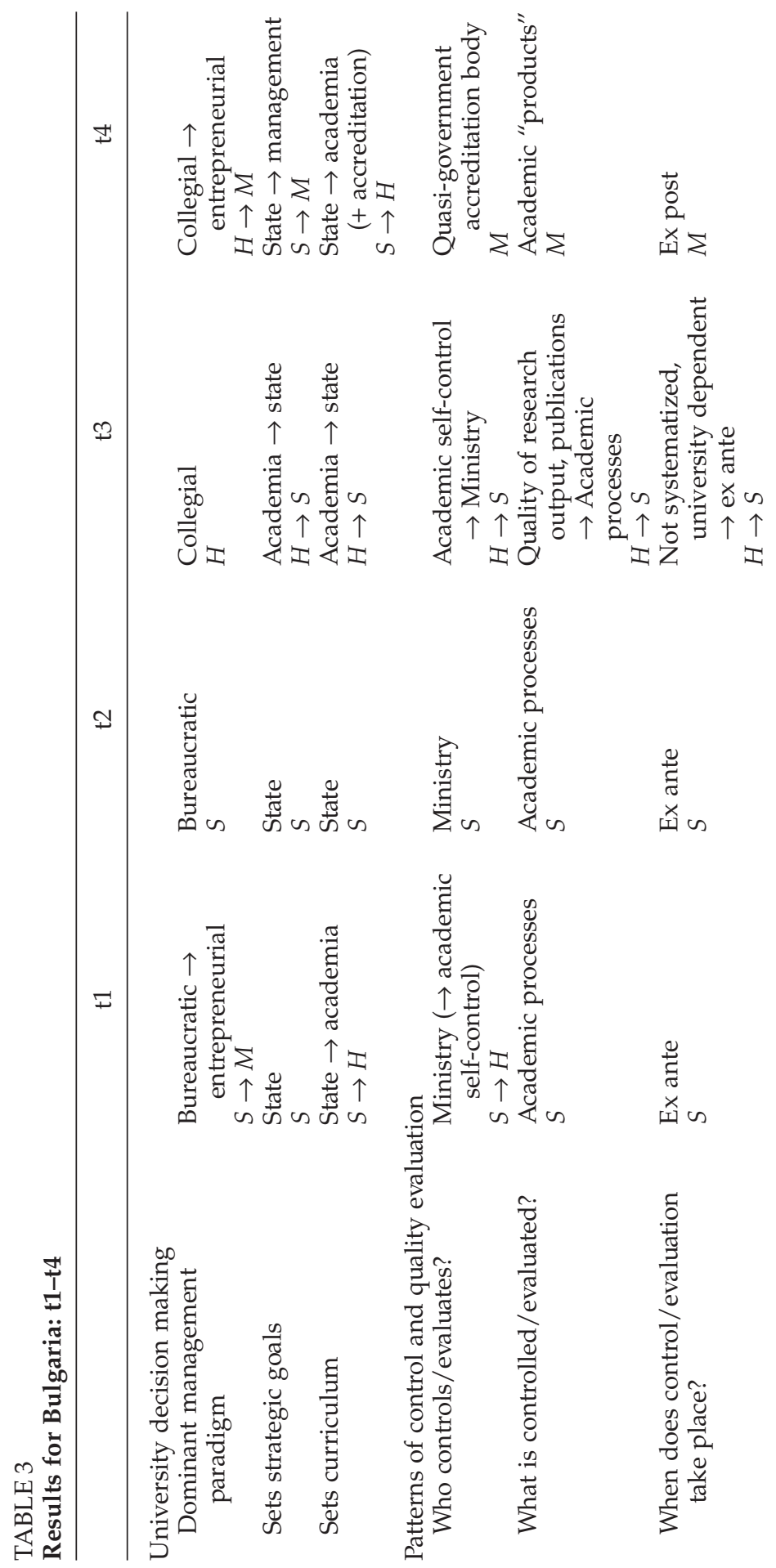




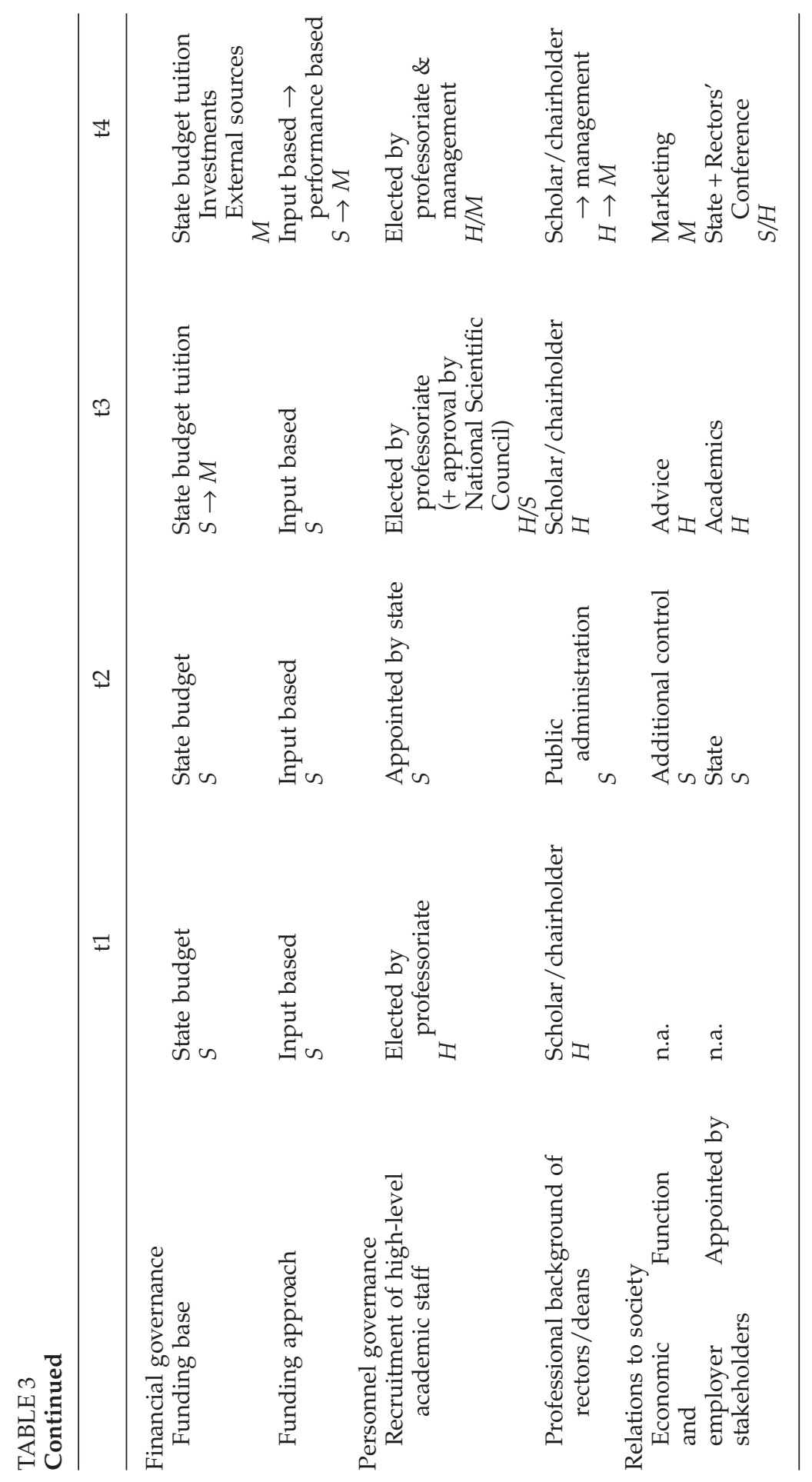


Romanian policymakers overtly feared looking like laggards-in particular with imminent prospects for intensified EU cooperation (Interviews $\mathrm{RO}-4$, RO-5). While the introduction of moderate study tuition was inspired by American practice, the British model was most attractive with regard to lump-sum funding and external procurement.

Yet historical legacies also continued to shape Romanian HE, some of which actually facilitated market-based governance. This is the case with the tight collaboration between industries and $\mathrm{HE}$, which is not only the consequence of the Ministry's support measures (e.g., taxation incentives), but also the forced collaboration between universities and industry under Ceauşescu (Interview RO-4). Moreover, academics have been inspired by the Humboldt orientation of the interwar phase (Sadlak 1995) to strengthen their collective interests. As a result, an "academic oligarchy" indeed snowballed in the 1990s (Interview RO-2), which resists the influence of external stakeholders and the abolition of tenure privileges. Although the chair model has returned to some institutions, many universities have successfully established management structures to counterbalance the professorial lobby and provide strategic leadership. Interestingly, the strengthening of the management level is also the result of domestic isomorphic processes, as Romanian universities have been keen to emulate two institutions broadly regarded as successful in procuring external funding, benefiting from international networking, and research output-Babeş-Bolyai University of Cluj-Napoca and Alexandru Ioan Cuza University of Iaşi (Interviews RO-1, RO-5).

Bologna has accelerated and reinforced the market-oriented trend in Romanian HE, having side effects on numerous issues. Policymakers tend to view the Bologna Process as a means of changing the functioning of universities and bringing them in line with the demands of globalization and the knowledge economy (Interview RO-3). The reform course consolidated under the Bologna banner has been defined as a springboard to move Romania closer to Europe, and lend legitimacy to its HE system. The pressure to join the EU-combined with the normative environment of Bologna-has prompted the Ministry and HE community to increasingly focus on institutional performance. A new system of accreditation inspired by Bologna guidelines was hence established in 2006, although the level of external stakeholder participation remains uncertain. The Bologna Process has also fostered the strengthening of university autonomy. Alluding to the Bologna Process, the state has relinquished control over accession conditions, size, personnel affairs, and research profiles, which are now determined exclusively by university management in cooperation with individual faculties (Interview RO-3). The rector's position has also been strengthened, allowing for entrepreneurial management and performance-based fund allocation (Table 4).

Altogether, the Bologna Process combined with the willingness to emulate Western practice has accelerated marketization trends in Romanian HE. If passed, current legislation would represent the most 


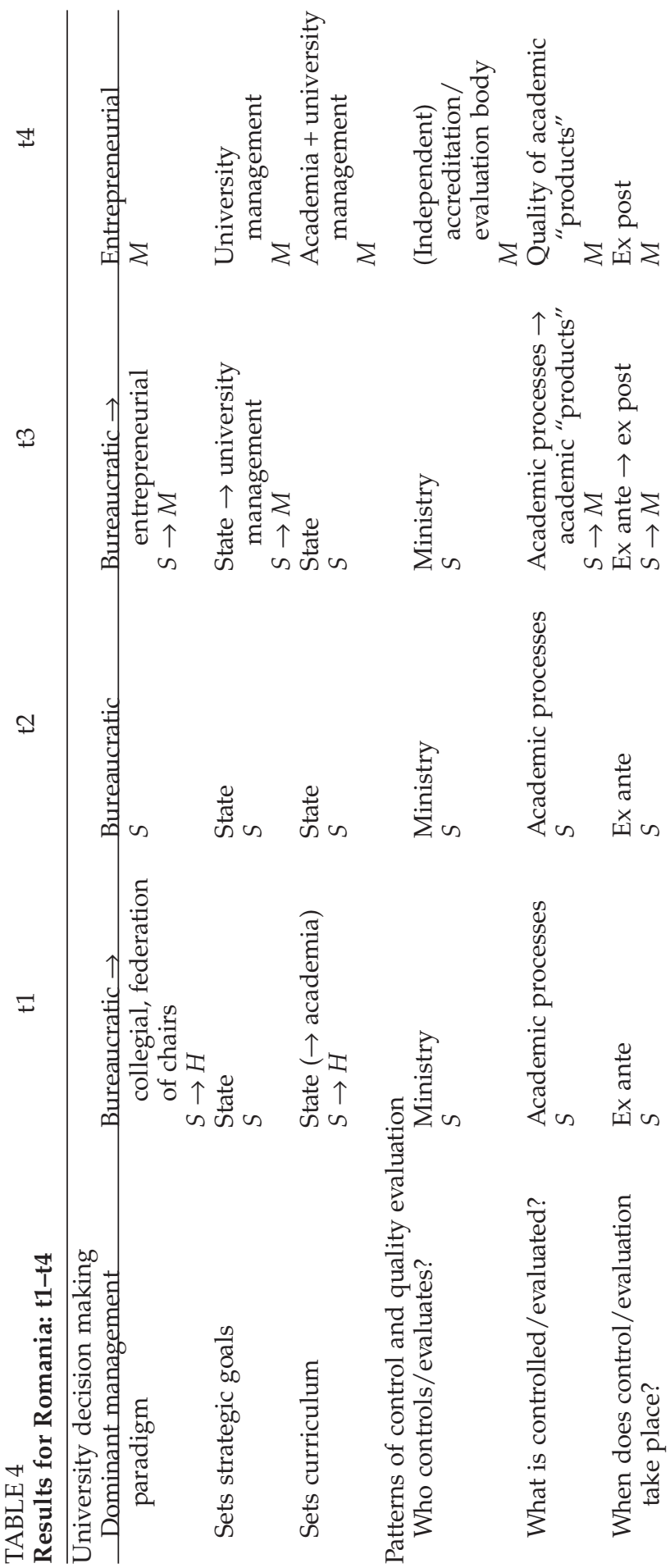




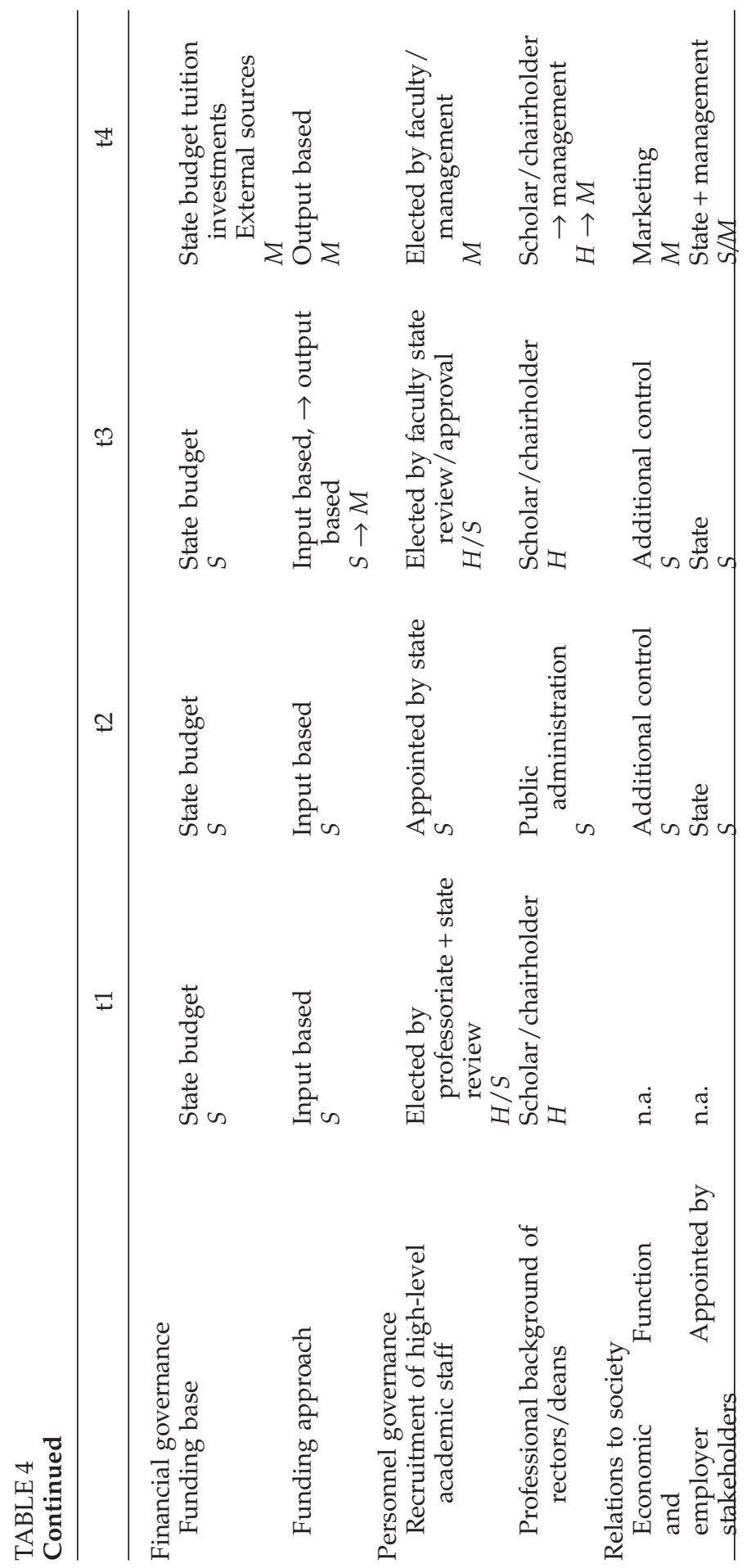


far-reaching expression of entrepreneurialism in the four examined countries, as the law prescribes close university-business cooperation. This is envisioned both at the university level and within a National Strategic Council, which would enable the Ministry to nominate business representatives to exert leverage over policy development (Interview RO-3).

\section{Poland: "Deflected" Isomorphism}

Poland stands out with its erratic and regionally differentiated HE traditions. Originally in line with the Humboldt tradition (Scott 2002, 141) and characterized by a tradition of vigorous academic resistance to outside meddling (Loss 2004, 109), Poland was integrated into the Soviet sphere of influence and succumbed to the ideological hegemony of communism. During several phases of relative political and economic openness however, Polish science and academics benefited from the greater permeability of the system to external influences, as contacts with Western science communities were partially tolerated (van Beek 1995).

Postcommunist developments in Poland follow two different storylines. On the one hand, Poland has the most developed private HE system in Europe, which emulates Western entrepreneurial models of funding and management (Interview PL-3). This has prompted many observers to classify the entire Polish system as market oriented (Duczmal 2006 , 25). The public university sector, on the other hand, has followed a similar storyline as the Czech Republic. This was manifested in $\mathrm{t} 3$ by a swift shift back to the chair system, the legal codification of extensive autonomy and decentralization. Hence, universities regained full procedural and substantive autonomy, while policymakers sought to establish a system of internal collegial governance. This resulted in the reestablishment of Academic Senates consisting of a majority of academics, students, and administrative personnel. The initial Humboldt orientation was also displayed by the lack of external stakeholder participation in governance.

To what extent have examples of best practice conveyed through transnational interlinkages impacted the development of Polish HE in the past 10 years? The evidence suggests that Poland still finds itself lodged between the market and academic oligarchy, and that the exogenous dimension has moderately impacted the direction of change. With regard to HE supply and demand, Poland stands out with its clear marketoriented stance, which has led not only to an explosion in private HE but also tremendous study course diversity. As concerns governance patterns in public institutions, however, only a slow shift away from decentralized academic self-rule has taken place, even in t4. Internal management structures remain bottom heavy and nonmanagerial, as university management does not operate with strategic goals and performance criteria (Interview PL-4; see also de Boer and Goedegebuure 2003, 224).

The funding scheme for public universities offers a mixed picture and the lack of reform is somewhat baffling for adherents to isomorphism 
theory. In the pre-Bologna phase, public HE funding in Poland was exclusively input based ${ }^{2}$ (Jongbloed 2003, 132). Like in the Czech system, national legislation prohibited tuition fees. However, this only applied to full-time students, as public institutions could charge tuition from nontraditional students, that is, part-time and weekend students, and those who do not pass entrance exams. However, in t4, Poland still clearly lags behind its CEE counterparts with regard to effectively channeling performance-related criteria into the funding scheme. First, lump sums received from the state are distributed evenly among individual faculties without regard to output. Second, institutions not only still receive insufficient governmental funding for operations but also are not rewarded for performance. Adherents to isomorphism theory will be surprised that Polish policymakers have not tapped into readily available innovative funding solutions despite the widespread consensus on the ineffectiveness of the system (Interview PL-4). This suboptimal situation is also compounded by still underdeveloped cooperation between universities and businesses.

Hence, it appears that transnational isomorphic forces driven by market rhetoric and managerialism have continually been deflected into the private sector. More specifically, instead of introducing entrepreneurial methods to public institutions, high-ranking academics were purportedly instrumental in establishing a new education sector (World Bank 2004, 28). After fulfilling daytime teaching obligations at public institutions, many professors delivered similar lectures at private institutions in the evening. As a result of this additional income, most professors found themselves in a relatively snug position and were thus not interested in output-based funding or additional performance incentives at public institutions (Interview PL-2). In other words, despite their immersion into the competitive structures of private colleges and transnational networks, the Polish professoriate showed little interest in introducing incentive-based instruments to public institutions. By maneuvering between both sectors, individual professors instead created their own minimarkets, which rewarded them for frequently redundant teaching activities.

Despite the very sluggish move away from chair system derived from prewar legacies (Interview PL-1), the Bologna Process is manifestly impacting the relationship between the state and HE. Like in Romania, universities are being granted greater autonomy and flexibility in exchange for accountability. For example, the Bologna Process inspired the creation of the State Accreditation Commission in 2001, which evaluates the quality of study programs ex post and has returned authority to the state to close ineffective programs. In exchange, the latest amendments of 2005 have granted universities more extensive personnel autonomy, devolving appointment and staffing discretion to the university level (Duczmal 2006, 948). Moreover, the abolishment of habilitation degrees was also inspired by British practice and current reforms in Germany (Interview PL-1), resulting in a shift away from the chair system unprec- 
edented in the examined countries. The state has also attempted to curtail the above described commitments to multiple institutions with a legislative amendment in 2005 (Table 5). ${ }^{3}$

As the ministry's reform blueprint (Strategia Rozwoju Edukacji na Lata 2007-2013) shows, the Bologna Process is not taken as mere "lip service" in Poland. Although the strategy still lacks concrete guidelines for implementation, it offers evidence that the ministry is attempting to use the Bologna Process to push for deeper reform and more external stakeholdership. An example is the establishment of various technology transfer centers as well as the Ministry's effort to stimulate ties between Polish regions (województwa) and HE along with an array of public-private partnerships (OECD 2006, 50). Hence, although long-standing historical legacies from $\mathrm{t} 1$ have manifestly reinforced academic self-rule in public universities, Polish HE is currently subject to a series of change-promoting factors: an emboldened Ministry, private sector competition, a growing service- and knowledge-based economy, and the normative environment of the Bologna Process.

\section{Conclusion}

If we compare the developments in higher education policy governance in the four analyzed countries, there does not appear to be a clear trend characterizing every country. First, it is clear that despite relatively similar starting conditions the differences in HE governance have increased since the system transformation. This is because the four countries have distanced themselves from the state-centered model to different degrees, with different speeds and in different directions. Second, it is apparent that the respective Western models, which provided reference for their reforms, vary in the phases before and after the initiation of the Bologna Process. In $\mathrm{t} 3$ all countries with the exception of Romania aligned themselves with the model of academic self-governance. As Neave $(2003,27)$ asserts, CEE academic policymakers evoked the ghost of Humboldt as an "act of faith, conviction, and political necessity" and as a radical alternative to state control. With its accent on unfettered scholarly freedom, the academic self-rule model was viewed by academic policymakers as a fundamental component of a democratic society and a means of protecting themselves from state influence (Scott 2002). This holds, in particular, for the Czech Republic and Poland and to a limited extent for Bulgaria. The problems resulting from lacking accountability, transparency, and executive guidance only had further institutional ramifications in Bulgaria in $\mathrm{t} 3$, as the state and Ministry reemerged to create a tight control cycle over funding and admissions. Thus, Bulgaria was the only country to experience a swift "detour" back toward the state-centered model in t3. In the Bologna phase we find a stronger orientation toward the market model in all four analyzed countries, albeit to very different degrees. In the Czech Republic, Poland, and Bulgaria, these developments are of a more 


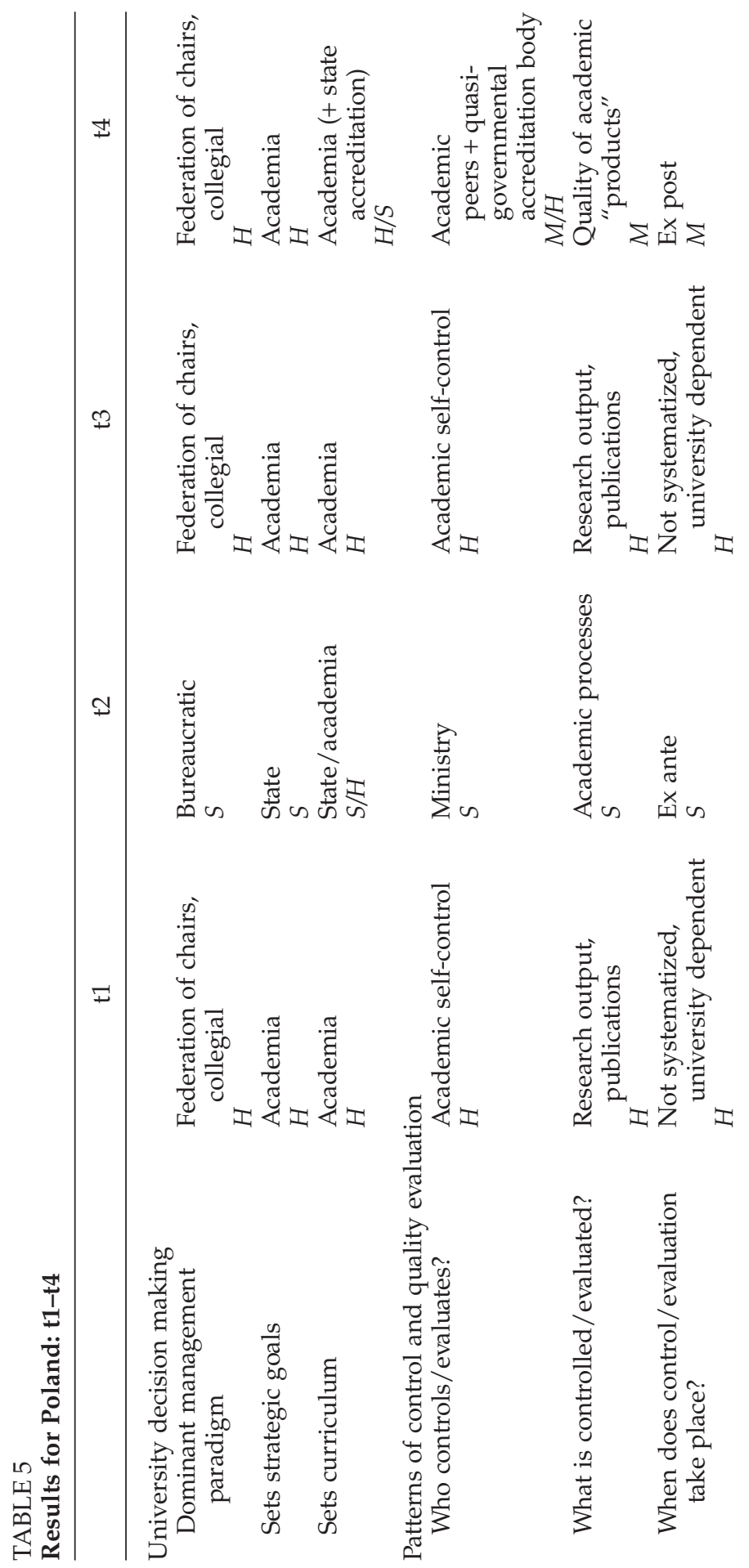




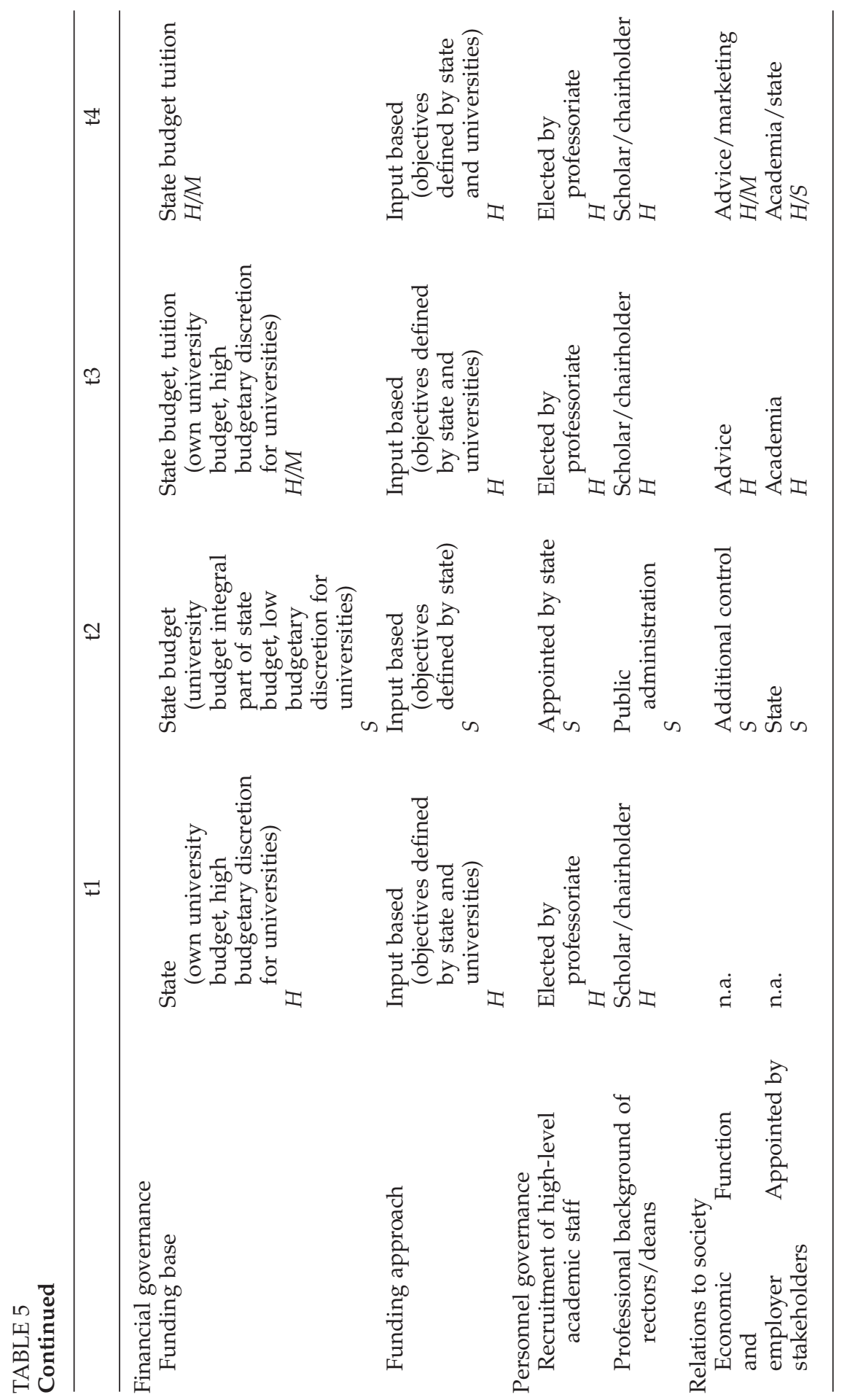


sporadic and rudimentary nature, while Romania has aligned itself very closely with the market-oriented model.

What are the theoretical implications of our empirical findings? First, the pace of change has proven to be sluggish in the traditionally Humboldtian systems of the Czech Republic and Poland, which drew heavily on the chair system with strong roots in the nineteenth century and earlier. This lends legitimacy to Hypothesis 3 concerning the sustaining impact of precommunist traditions. However, historically legitimized institutions per se explain do not explain alone why Humboldtianism initially was the anchor point toward which Poland, the Czech Republic, and, initially, Bulgaria converged. Although references to preexisting models were frequently made in the Polish and Czech contexts, the resulting "back to the future" policies were also tailor-made to the present-day exigencies of the academic community. The Humboldt-oriented model not only was an expression of the deep aversion to state and external intervention but also offered the reinvigorated academic community the "best of both worlds." In other words, the state continued to finance HE in full but remained nearly powerless with regard to teaching, research, administrative, and procedural matters. This enabled academics to establish institutions of "academic democracy" while maintaining their state funding base. By devolving power to the lowest level (chairs and faculties), the reinstated institutions also had a reinforcing impact and have hindered the overarching, executive-guided policy change, which occurred in Romania.

Yet how did Hypothesis 4 concerning the impact of communist pathdependencies fare upon analysis of the data? The communist pathway only bears weak explanatory power for contemporary developments. The $t 2$ legacies of state monopoly and state-centeredness were quickly rubbed away in the Czech Republic, Poland, and Bulgaria, regardless of the nature of state control under communism. All three academic communities subverted the vestiges of the omnipotent state and moved away from the state-centered model practically "overnight." In Romania, the legacy of an omnipotent state did have a stronger impact in $\mathrm{t} 3$ but also must be seen in conjunction with the absence of an assertive academic community. And with regard to 44 , all countries had clearly moved away from the stateauthority model and only very few path dependencies from $\mathrm{t} 2$ could be identified. Especially the strong aversion to tuition in the Czech Republic and Poland may have its roots to egalitarian attitudes from $\mathrm{t} 2$. Aside from this, the Soviet model of heavy bureaucracy and state dirigisme appears as an aberration in the historical continuity of Polish, Czech, and Bulgarian HE. In contrast to the market or the Humboldt model, the state model neither constituted a dominant approach advocated at the transnational level nor was it supported by domestic stakeholders and political elites.

Hypothesis 1, which predicted divergence in HE policies in the preBologna phase ( $\mathrm{t} 3$ ) as a result of different institutional interlinkages, was partially confirmed by the data, as the four systems of HE governance diverged by the mid-1990s. Bulgaria moved away from the Humboldt 
model toward the state-centered paradigm, while Romania was preparing to move away from state centrism toward marketization. However, different transnational institutional interlinkages were not the explanatory factor for divergence, as transnational communication only had a weak impact on HE governance in $\mathrm{t} 3$, with the exception of the reforms initiated in 1996-1997 in Romania. These developments also reveal a general pattern of policymaking in $\mathrm{t} 3$. Immediately after the collapse of communist regimes, securing autonomy was paramount to academic policymakers. Hence, the policy process was dominated by national exigencies and, in the Polish and Czech cases in particular, the recourse to historical models. During and subsequent to this period, all four countries engaged in various forms of transnational communication and bilateral policy exchange through the TEMPUS program and the involvement of the World Bank and OECD. However, their impact remained, for the most part, restricted to capacity building, that is, system expansion, lifelong learning, without fostering shifts in governance paradigms.

As already indicated, the sequence of events lends support to Hypothesis 2 concerning convergence in the Bologna phase. In all four countries we find evidence that the Bologna Process has played an important role in triggering national reform processes aimed at increased marketization. The Bologna-based activities have enabled CEE policymakers to meet and exchange reform strategies and ideas, which in various cases exceed the actual objectives of the Bologna Declaration. In particular in the case of Romania and Bulgaria, "Bologna" entails more than the establishment of the agreed "EHEA," but a multitude of formal and informal exchanges of best practice. The conducted interviews have revealed that the marketoriented model dominates discourse on the Bologna platform and that Bologna is increasingly perceived as means of legitimization of such market-based strategies and has hence accelerated their spread at the national level. In other words, the efforts at Europeanizing HE have compelled national executives to engage in a more responsive mode of behavior with the aim of increasing the accountability, efficiency, and viability of HE institutions.

Yet we must again differentiate here, as isomorphic processes "kicked in" at different time periods, with different momentum and with different consequences. Although policy experts from all countries stress the increased will to engage in policy borrowing from Western Europe in t4, institutional isomorphism has had the most profound impact in Romania, triggering a consistent shift toward market-oriented governance. Bulgaria, Poland, and the Czech Republic have also demonstrated the gradual emulation and transfer of instruments to enhance competition and institutional performance, but are far from being market-based systems (Figure 1).

Altogether, the evidence has demonstrated that the Bologna Process is a more integrative convergence-promoting force than previous forms of transnational cooperation. Although previous arrangements (OECD, 
FIGURE 1

\section{Policy Developments Applied to Clark's Triangle}

\section{Bulgaria}

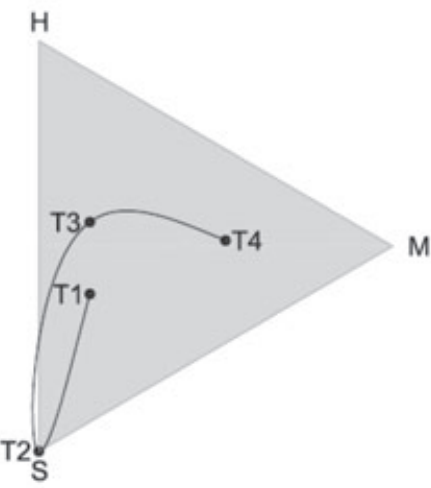

Poland

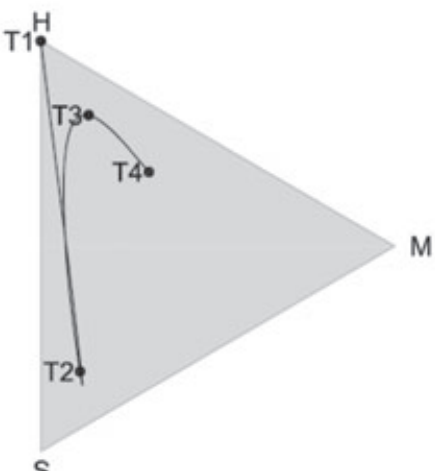

\section{Czech Republic}

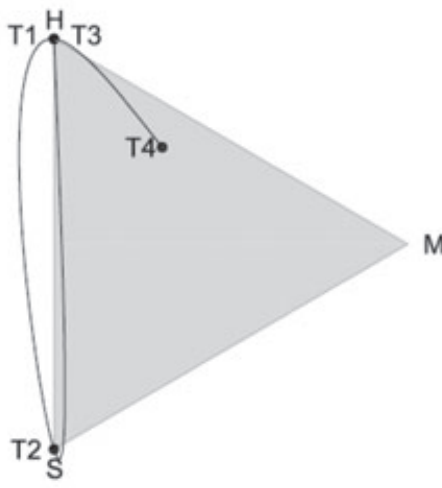

Romania

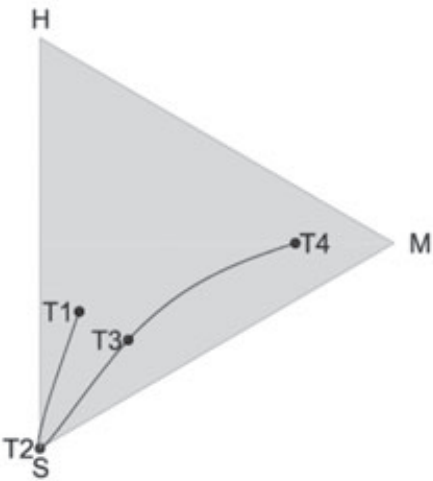

H, Humboldtian Model of Academic Self-Rule; M, Market-Oriented Model; S, State-Centered Model.

World Bank, individual academic interlinkages) offered know-how and promoted concrete principles and policy strategies, the Bologna Process has put a transnational lens on domestic HE policymaking and generated a greater awareness of the fallibility of existing arrangements.

In general though, our findings indicate that isomorphism induced at the transnational level comes in different shapes and can generate different results, even in a highly integrative transnational normative environment. The Czech Republic followed a pattern of selective isomorphism of individual policy instruments tailor-made to the sensitivities of the cohesive academic community. Poland has frequently deflected isomorphic forces to the private sector, although recently a gradual approximation with the market model can also be ascertained in the public sector. Romania can be 
regarded as a case of fully fledged isomorphism resulting in a broad paradigmatic overhaul of the system, while isomorphic change toward the market paradigm has been watered down in Bulgaria due to legislative and policymaking constraints. Finally, our results have also revealed that policy change and convergence can only be fully explained by combining theoretical arguments of both historical and sociological institutionalism. In other words, from the perspective of policymakers it is not necessarily a matter of pitting legacies and transnational communication against one another; rather, it is a matter of combining them in a manner that is most expedient in view of national institutional peculiarities.

\section{Acknowledgments}

We gratefully acknowledge generous research funding from the Thyssen Foundation as well as the very constructive comments of three anonymous referees and the editors of Governance.

\section{Notes}

1. This is exemplified by the accreditation system, as disagreements persisted over program versus institutional accreditation (Interview BG-6). After foundation in 1995, operations did not begin until 1998.

2. Weighted number of students and teaching staff with scientific degrees.

3. See Polish Law on Higher Education, Articles 264, 265, which limits academic employment to two institutions in total.

\section{References}

Bennett, Colin. 1991. "Review Article: What Is Policy Convergence and What Causes It?" British Journal of Political Science 21: 215-233.

Berlin Communiqué. 2003. "Realizing the European Higher Education Area." Communiqué of the Conference of Ministers Responsible for Higher Education in Berlin, September 19.

Bleiklie, Ivar. 2001. "Towards European Convergence of Higher Education Policy?" Higher Education Management 13 (1): 9-29.

Boiadjieva, Pepka. 2005. "Modern Universities-Between Autonomy, Accountability and Responsibility." Discussion paper prepared for the Working Group on developing a new law on higher education in Bulgaria at the Ministry of Education and Science. 〈http://www.see-educoop.net/education_in/pdf/ modern_univer-bul-enl-t05.pdf $\rangle$. (June 6, 2005).

Bologna Declaration. 1999. Joint Declaration of the European Ministers of Education.

Cerych, Ladislav. 2002. "Higher Education Reform in the Czech Republic: A Personal Testimony Regarding the Impact of Foreign Advisers." Higher Education in Europe 27: 1-2.

Clark, Burton. 1983. The Higher Education System. Berkeley, CA: University of California Press.

- 1998. Creating Entrepreneurial Universities: Organizational Pathways of Transformation. Oxford: Pergamon-Elsevier Science.

Corbett, Anne. 2005. Universities and the Europe of Knowledge. Basingstoke: Palgrave.

de Boer, Harry, and Leo Goedegebuure. 2003. "New Rules of the Game? Reflections on Governance Management, and Systems Change." In Real-Time 
Systems-Reflections on Higher Education in the Czech Republic, Hungary, Poland, and Slovenia, ed. Jon File and Leo Goedegebuure. Enschede: Logo CHEPS, University of Twente.

Dill, David. 1997. "Higher Education Markets and Public Policy." Higher Education Policy 10 (3-4): 167-185.

DiMaggio, Paul, and Walter Powell. 1991. "The Iron Cage Revisited: Institutionalised Isomorphism and Collective Rationality in Organizational Fields." In The New Institutionalism in Organizational Analysis, ed. Walter Powell and Paul Dimaggio. Chicago: University of Chicago Press.

Dolowitz, David, and David Marsh. 2000. "Learning from Abroad: The Role of Policy Transfer in Contemporary Policy Making." Governance 13: 5-24.

Drezner, Daniel W. 2001. "Globalization and Policy Convergence." The International Studies Review 3: 53-78.

Duczmal, Wojciech. 2006. "Poland." In International Handbook of Higher Education, ed. James Forest and Philip Altbach. Dordrecht: Springer.

European Commission. 2003. "Higher Education in Europe." 〈http:// europa.eu.int/comm/education/higher.html〉. (June 15, 2008).

Georgieva, Patricia. 2002. Higher Education in Bulgaria. CEPES Bucharest. UNESCO Monographs on Higher Education.

Gocheva, Dimka. 2002. "Apologia Declarationis Boloniensis contra murmurantes." International Policy Fellowship Program, Budapest. 〈http:// www.policy.hu/gocheva/text/bologna.html). (February 15, 2007).

Heichel, Stephan, Jessica Pape, and Thomas Sommerer. 2005. "Is There Convergence in Convergence Research?" Journal of European Public Policy 12 (5): 817840.

Hendrichová, Jana, and Helena Šebková. 1995. “Decision-Making in Czech Higher Education after November 1989." In Higher Education Reform Processes in Central and Eastern Europe, ed. Klaus Hüfner. Frankfurt: Peter Lang.

Holzinger, Katharina, Christoph Knill, and Thomas Sommerer. Forthcoming. "Environmental Policy Convergence: The Impact of International Harmonization, Transnational Communication, and Regulatory Competition." International Organization.

Huisman, Jeroen and Marijk Van der Wende. 2004. "The EU and Bologna: Are Supra- and International Agendas Threatening Domestic Agendas?" European Journal of Education 39 (3): 349-357.

Jongbloed, Ben. 2003. "Institutional Funding and Institutional Change." In RealTime Systems-Reflections on Higher Education in the Czech Republic, Hungary, Poland, and Slovenia, ed. Jon File and Leo Goedegebuure. Enschede: Logo CHEPS, University of Twente.

Knill, Christoph. 2005. "Introduction, Special Issue." Journal of European Public Policy 12 (5): 764-774.

Kotásek, Jiří. 1996. "Die Hochschulpolitik der Tschechoslowakei, 1945-1989." In Hochschulpolitik in Ostmitteleuropa 1945-1995, ed. Peter Bachmaier. Frankfurt am Main: Peter Lang.

Loss, Christopher. 2004. "Party School: Education, Political Ideology, and the Cold War." Journal of Policy History 16 (1): 99-116.

Maassen, Peter, and Johan Olsen. 2007. University Dynamics and European Integration. Dordrecht: Springer.

Marga, Andrei. 1998. The Reform of Education in 1999. Agenţia Naţionala Socrates. Bucharest Alternative.

- 2002. "Reform of Education in Romania in the 1990s: A Retrospective." Higher Education in Europe 27 (1-2): 123-135.

Martens, Kerstin, Alessandra Rusconi, and Katrin Leuze. 2007. New Arenas of Education Governance-The Impact of International Organizations and Markets on Educational Policymaking. Houndmills, Basingstoke: Palgrave. 
Mateju, Petr. 2004. "Czech Higher Education Still at a Crossroads." The Prague Post, November 18, 2004. 〈http://www.praguepost.com/P03/2004/Art/1118/ opin4.php $\rangle$. (February 19, 2007).

Matějů, Petr, and Natalie Simonová. 2003. "Czech Higher Education Still at a Crossroads." Sociologický Časopis 39 (3): 393-410.

McDaniel, Olaf. 1996. "The Paradigms of Governance in Higher Education Systems." Higher Education Policy 9 (2): 137-158.

Mihailescu, Ioan, and Lazar Vlasceanu. 1994. "Higher Education Structures in Romania." Higher Education in Europe XIX (4): 79-93.

Neave, Guy. 2003. "On the Return from Babylon: A Long Voyage around History, Ideology and Systems Change." In Real-Time Systems-Reflections on Higher Education in the Czech Republic, Hungary, Poland, and Slovenia, ed. Jon File and Leo Goedegebuure. Enschede: Logo CHEPS, University of Twente.

Neave, Guy and Frans van Vught. 1991. Prometheus Bound: The Changing Relationship between Government and Higher Education in Western Europe. Oxford: Pergamon Press.

Nicolescu, Luminiţa. 2002. "Reforming Higher Education in Romania." European Journal of Education 37 (1): 91-100.

Offe, Claus. 1993. "Designing Institutions for East European Transitions." Public Lecture Series. Collegium Budapest. 〈http://www.colbud.hu/main_old/ PubArchive/PL/PL09-Offe.pdf). (April 16, 2007).

Olsen, Johan. 2007. "The Institutional Dynamics of the European University." In University Dynamics and European Integration, ed. Peter Maassen and Johan Olsen. Dordrecht: Springer.

Organisation for Economic Co-operation and Development (OECD). 1992. Review of Higher Education in the Czech and Slovak Federal Republic. Examiner's Report and Questions.

—. 2006. "OECD Thematic Review of Tertiary Education: Country Background Report for Poland," prepared by Małgorzata D bঞsowa-Szefler and Julita Jabłecka-Prysłopska. Warsaw.

Phillips, David. 2005. "Policy Borrowing in Education: Framework for Analysis." In International Handbook on Globalisation, Education and Policy Research, ed. Joseph Zajda. Dordrecht: Springer.

Polish Law on Higher Education. 2005.

Prague Communiqué. 2001. "Towards the European Higher Education Area." Communiqué of the Meeting of the European Ministers in Charge of Higher Education in Prague, May 19.

Radó, Péter. 2001. Transition in Education-Policy Making and the Key Educational Policy Areas in the Central-European and Baltic Countries. Budapest: Open Society Institute. 〈http://www.osi.hu/iep/papers/transit.pdf). (March 14, 2005).

Rakic, Vojin. 2001. “To Converge or Not Converge: The European Union and Higher Education Policies in the Netherlands, Belgium/Flanders and Germany." Higher Education Policy 14: 225-240.

Sadlak, Jan. 1995. "In Search of the "Post-Communist University-The Background and Scenario of the Transformation of Higher Education in Central and Eastern Europe." In Higher Education Reform Processes in Central and Eastern Europe, ed. Klaus Hüfner. Frankfurt: Peter Lang.

Schimank, Uwe. 2002. "Governance in Hochschulen." Speech given at "Professionelles Wissenschaftsmanagement als Aufgabe" organized by the Zentrums für Wissenschaftsmanagement, October 22. Wissenschaftszentrum Bonn.

Scott, Peter. 1993. "Reflections on the Transatlantic Dialogue." Policy Perspectives 5 (1): $18-58$.

2002. "Reflections on the Reform of Higher Education in Central and Eastern Europe." Higher Education in Europe 27 (1-2): 137-152. 
Slantcheva, Snejana. 2004. "The Limits of Institutional Reflexivity in Bulgarian Universities." Higher Education Policy 17: 257-268.

Sporn, Barbara. 2006. "Governance and Administration." In International Handbook of Higher Education. Part One, ed. Philip Altbach and James Forest. Dordrecht: Springer.

Stastna, Vera. 2001. "Internationalisation of Higher Education in the Czech Republic-The Impact of European Union Programmes." European Journal of Education 36 (4): 473-491.

Stone, Diane. 2004. "Transfer Agents and Global Networks in the 'Transnationalization' of Policy." Journal of European Public Policy 11 (3): 545-566.

Tucker, Aviezer. 2000. "Reproducing Incompetence: The Constitution of Czech Higher Education." East European Constitutional Review 9 (3): 94-99.

Vaira, Massimiliano. 2004. "Globalization and Higher Education Organizational Change: A Framework for Analysis." Higher Education 48: 483-510.

van Beek, Ursula. 1995. "The Case of Poland." In Transformation mittel- und osteuropäischer Wissenschafssysteme, ed. Renate Mayntz, Uwe Schimank, and Peter Weingart. Opladen: Leske + Budrich.

Walter, Thomas. 2006. "Hochschulbildung und Hochschulpolitik in Europa: Das Bologna-Projekt als Prozess einer doppelten Neuordnung." In LernOrt Universität. Umbruch durch Internationalisierung und Multimedia, ed. Georg Simonis and Thomas Walter. Wiesbaden: VS Verlag für Sozialwissenschaften.

Witte, Johanna 2006. "Change of Degrees and Degrees of Change: Comparing Adaptations of European Higher Education Systems in the Context of the Bologna Process." Ph.D. dissertation, Universiteit Twente, CHEPS, Enschede.

World Bank. 2004. Tertiary Education in Poland, Edition I. Warsaw: Protea-Taff Studio.

\section{Appendix: Interviewed Experts}

CZ-1: Director, Centre for HE Studies (CSVS-Prague)

CZ-2: CSVS-Prague, Lecturer, Charles University (Prague)

CZ-3: CSVS-Prague

CZ-4: Czech university chancellor

CZ-5: HE Development Unit, Ministry of Education, Youth and Sports

CZ-6: CSVS-Prague

BG-1: University vice-rector

BG-2: University professor

BG-3: Director of Center for HE Research

BG-4: Bulgarian HE Council; university rector

BG-5: Parliamentary Committee on Education and Science; formerly: Deputy Minister for HE

RO-1: University rector; formerly: Minister of National Education of Romania

RO-2: Deputy Director of UNESCO-CEPES, university professor; formerly: State Secretary for HE

RO-3: Unit for HE, Ministry of Science and Education

RO-4: University pro-rector; formerly university rector

RO-5: University rector: since November 2007 Member of European Parliament

PL-1: Coordinator of TEMPUS project; Bologna Promoter Team

PL-2: Center for HE Policy Studies (CBPNiSzW), University of Warsaw, Senate Committee for HE Organization and Development

PL-3: Pro-Rector Polish private university

PL-4: University professor; Director of the Center for Public Policy, Adam Mickiewicz University Poznań; HE Policy Expert to EU Commission, USAID, OECD, World Bank, UNESCO, OSCE 